\title{
Moral Reasoning, Academic Dishonesty, and Business Students
}

\author{
Charles H. Bélanger, Ph.D. (Corresponding author) \\ Professor of Management \\ Faculty of Management, Laurentian University \\ Ramsey Lake Road, Sudbury, Ontario, Canada P3E 2C6 \\ E-mail: charles5@magma.ca \\ Valorie M. Leonard, MBA, FCA \\ Professor of Accounting \\ Faculty of Management, Laurentian University \\ Ramsey Lake Road, Sudbury, Ontario, Canada P3E 2C6 \\ E-mail: vleonard@laurentian.ca \\ Rolland LeBrasseur, Ph.D. \\ Professor of Organizational Behavior \\ Faculty of Management, Laurentian University \\ Ramsey Lake Road, Sudbury, Ontario, Canada P3E 2C6 \\ E-mail: rlebrasseur@laurentian.ca
}

Received: March 21, 2012

doi:10.5430/ijhe.v1n1p72
Accepted: April 23, 2012

Published: May 15, 2012

URL: http://dx.doi.org/10.5430/ijhe.v1n1p72

\begin{abstract}
This study links moral reasoning, academic dishonesty, and business students. Undergraduate business students $(\mathrm{N}=1357)$ from eight Ontario (Canada) universities responded to a survey to express their perceptions and expectations of their academic environment and the variables that can help them to understand what is morally right and what is morally wrong. Results revealed these emerging adults welcome some moral guidance but they are not inclined to encumber themselves with too many rules. Their main expectations revolve around self-confidence, independence of thought and action, acceptance of responsibility for themselves, and what academic dishonesty involves. The authors discuss these findings in the context of moral development of emerging adults who are challenged to achieve identity coherence and ethical judgment. For their part, business schools have the obligation to offer enriching academic experiences and train values-based leaders without preaching 'morality'.
\end{abstract}

Keywords: Moral development, Moral reasoning, Ethical behavior, Business ethics, Emotional intelligence, Academic dishonesty, Business students, Emerging adults, Plagiarism

\section{Introduction}

The link between moral reasoning and ethical/moral behavior has produced an extensive research-based body of knowledge generally associated with two multifaceted schools of thought: one lead by moral philosophers and the other by social scientists (Ho, Vitell, Barnes, \&Desborde, 1997; Wimbush, 1999). According to key philosophical theories (Cavico \& Mujtaba, 2009; Frederiksen, 2010; Kujala, Lämsä, \& Penttila, 2011) such as ethical egoism (short- and long-term self-interest), ethical relativism (when in Rome, do what the Romans do!), and utilitarianism (the ends justify the means), individuals make moral determinations of their conduct based on consequences, be it onto themselves or to others. In addition to these consequentialist theories, there are other non-consequentialist approaches based on the virtue theory and/or Kantainism (Categorical Imperative), whereby the action itself or the means must pass the ultimate ethics test (sometimes described as the Kingdom of Ends test) regardless of consequences (Cavanagh, Moberg, \& Velasquez, 1981; Smith \& Dubbink, 2011). 
On the other hand, social scientists have labored for more than four decades on the concept of cognitive moral development to discover that an individual's morality follows a distinct and universal pattern based on a number of individual, contextual, and issue-related factors (Kohlberg, 1969, 1976; Rest, 1986; Trevino, 1992; Jones, 1991; Rest \& Narvaez, 1994; Wimbush, 1999; Lounsbury, Huffstetler, Leong, \& Gibson, 2005; O’Fallon \& Butterfield, 2005; Jorgensen, 2006, Levy \& Rakovski, 2006; Hunt \& Vitell, 2006; Ho \&Redfern, 2010). Most of these reason-based studies assume a student's cognitive moral development is not optimum until the student is able to analyze the consequences of his/her decisions on oneself and others. Such a heightened state of thinking is only possible when an individual can string four psychological processes: assess the situation and the context, select a course of action within acceptable norms, recognize the importance of moral behavior over other considerations, and show the fortitude to behave morally (Rest, 1986).

While in school, it is arguable whether students face a more important ethical issue than the one revolving around academic dishonesty and the connotations it carries in the workplace. This is critical considering the increased public exposure of opaque deals, unethical practices, and illegal activities in and around boardrooms (Iyer \& Eastman, 2006). Research indicates that those who cheat in college will continue to engage in dishonest activities in other contexts (Beck \&Ajzen, 1991; Sims, 1993; Allmon, Page, \& Roberts, 2000; Harper, 2006; Karassavidou \& Glaveli, 2007). As McLafferty \& Foust (2004, p.186) stated, "every profession has a holy grail that involves an element of trust necessary for that profession to survive and thrive". It stands to reason that university students' expectations of what is professionally acceptable will be impacted by what they have learned in school as acceptable behavior, whether their moral character has been enhanced or not (Heyneman, 2011). Students will take notice of the sanctions imposed by their university if they are caught plagiarizing or cheating. They will also pay attention to deviations in organizational integrity such as breaches in institutional ethics committed by staff and governors as well as classroom improprieties perpetrated by faculty (Heyneman, 2011).

\section{The Focus of This Study}

Without attempting to judge which of the two distinct schools is more appropriate to apply to the study of ethical decision making, this study will be modeled mostly on the cognitive moral development (hereafter, CMD) theory found to be a widely used approach to study variations in individuals' ethical (unethical) decision making. The research question purports to find out whether students, as emerging adults, expect their university studies to help them learn what is morally right and what is morally wrong behavior, and as a result, raises the discussion about which elements of their campus life they long for assistance to achieve that goal.

It is hypothesized that students are in search of moral directions and welcome guidance from various avenues as long as it is not perceived as preaching or moralizing. Their responses will be analyzed by investigating a survey sample of undergraduate business students from eight Canadian universities and looking at their perceptions of the important factors in their academic environment that may foster their moral reasoning effectiveness.

The subsequent sections of this article delve on the pros and cons encountered in the literature about the teaching of business ethics, the various ethical theories with a focus on the CMD theory, and why business students are often targeted in academic misconduct studies. After explaining the methodology, the authors follow a typical course by presenting the results, discussing their relevance in broader terms, and suggesting some implications.

\section{Research Review \\ 3.1 Rationale for Business Ethics Education}

Learning Standard 15 of the US-based Association to Advance Collegiate Schools of Business (AACSB, 2011, p. 71) has embedded management-specific knowledge and skills associated with "ethical understanding and reasoning abilities" as well as "ethical and legal responsibilities in organizations and society" in accredited degree programs. The European Quality Improvement System (EQUIS) promotes a similar thrust. There exists a debate among researchers about whether tertiary education students are already too firmly established in their character for ethics education to reshape their instrumental values (Allen, Bacdayan, Berube-Kowalski, \& Roy, 2005; Low, Davey, \& Hooper, 2008). They contend that informing future lawyers, doctors, business persons, police officers, and accountants of what constitutes ethical behavior and what the penalties might be if they engage in unethical behavior is one thing; making these same individuals behave more ethically is quite another.

However, studies are generally supportive of the concept of (business) ethics education (Hooker, 2004; Harris, 2008; Neubaum, Pagell, Drexler, McKee-Ryan, \& Larson, 2009; Cavico \& Mujtaba, 2009; Warnell, 2010; Saat, Porter, \& Woodbine, 2010). The rationale behind promoting ethical reflection in the classroom hinges mostly on three values: 1) legality as a consequence of business failures such as Arthur Andersen (USA), Tyco International (Bermuda), Shell (The Netherlands), Parmalat (Italy), Satyam Computer Services (India), and HIH (Australia); 2) morality in an effort to bolster 
the moral reasoning capacity of students; and 3) social obligation to effect the 'character' of individuals, organizations, and society in a positive way (Harris, 2008; Cavico \& Mujtaba, 2009). Both sides of this debate can be better understood when viewed as part of the wider discourse on ability and skill, or when determining whether creating potential in human beings can be actualized as they emerge into adulthood.

Undergraduate university students between the ages of 18 and 25 continue to develop their abilities and identity. Arnett $(2000,2004)$ considers them emerging adults who: a) are exploring themselves and what life has to offer them; b) face particular challenges because of their growing autonomy but lack relative experience to guide them; and c) are eager to explore and come to grips with the complex issues that will affect them (e.g., career, commitment to others). It follows that their ethical reasoning is intensifying as part of their identity development (exploration and commitment to values). While at university, they pursue their career objectives through their academic program, and prepare for their journey into the "working world". They also participate in the campus experience of making new friends, indulging in adult pleasures, and making up their own minds on academic and societal issues (Arnett, 2007a, 2007b). From an ethical perspective, both levels of interaction are rich opportunities to practice moral reasoning in a context where they have to assign priorities to a range of moral alternatives (Rest, Thoma, Moon, \& Getz, 1986; Rest \& Deemer, 1986).

These formative years are particularly challenging since early research (Kohlberg, 1969) as well as follow-up studies (Thoma, 1985; Rest et al., 1986, 1999; Rest \& Deemer, 1986; Goolsby \& Hunt, 1992) have concluded the highest stages of moral judgment are likely not reached until late twenties and beyond. These researchers have also found that years of formal education and age, in this order, have been the most consistent correlatives of CMD, although it is not clear what accounts for this relationship. These authors have argued that education is a proxy variable for other kinds of life experience. Rest (1988) has even pushed his argument to a new level by affirming that any 20 year-old of good general character needs special education to function ethically in professional situations. This is similar to any logical 20 year-old needing special training to function as a lawyer or an accountant.

\subsection{Normative Cognitive Moral Development Models}

Inspired by Piaget's seminal work (1932) on moral development in children, Kohlberg (1969) connected CMD and moral action in a theory labeled the sequential stages of moral reasoning. Kohlberg's theory (1969) is composed of three levels consisting of two stages each. The first level (preconventional or egocentric) is based on the necessity to obey rules and to avoid punishment, just as a child would obey an adult person. Morality revolves around finding the means to serve one's own interests (stage 1) and exchanging favors or making deals (stage 2) as long as one gets away with it. In the second level (conventional), individualistic morality is gradually replaced by a morality separated from adult authority figures. It ranges from a duty and responsibility to fulfill what is expected of us by family, peer groups, and significant others to gain approval and trust (stage 3), to a certain consideration of the rules of order of the broader environment expressed as various societal systems put in place for the common good (stage 4). According to Kohlberg, most citizens can be positioned at either stage 3 or 4 of the conventional level. Finally, the third level (postconventional or autonomous) seeks to produce the greatest good for the greatest number by recognizing some non-relative values (stage 5) and ultimately by freely choosing universal and moral principles of justice because it is the right thing to do (stage 6). These stages also resonate with philosophical consequentialist and non-consequentialist theories as alluded earlier.

The CMD theory became the bedrock for followers who designed revised models and tests based on Kohlberg's hierarchical pioneering approach. Some of the most cited are the Defining Issue Test (Rest, 1986; Rest \& Narvàez, 1994), the Person-Situation Interactionist model (Trevino, 1986), the Issue-Contingency Model (Jones, 1991), the Deontological (norms and environment) or Teleological (stakeholders, consequences, personal characteristics) Evaluation model (Hunt \& Vitell, 1986, 1993), the Action-Controlled model (Ferrell, Gresham, \& Fraedrich,1989), and the Moral Judgment Test (Lind, 2008). The common tenets of these models and tests are that the ethical decision-making process is multidimensional; that it makes use of the interplay between cognition, affect, and behavior; and that it takes into account individual, situational, and issue-specific conditions (Ho et al., 1997; Wimbush, 1999; Ho \& Redfern, 2010).

The CMD theory has weathered the test of time in spite of some criticisms aimed at its gender- and culture-free claims to universality. As examples, let us mention Gilligan (1998) who argued a woman's way to resolve moral dilemma issues was more care-oriented than justice-oriented. Hence, women presumably had a different developmental pathway leading to different endpoints. After considerable work critiquing Kohlberg's findings, Gilligan's gender difference hypothesis was never unequivocally substantiated; instead her contribution was seen as a refinement of Kohlberg's approach rather than irrefutable proof that women experienced different stages of morality development (Reed, 1997; Rest, Narvaez, Bebeau, \& Thoma, 1999; Jorgensen, 2006). In fact, meta-analyses reported by Thoma (1985) observed higher scores among females, albeit not statistically significant. 
Another early criticism levied against the CMD approach focused on the lack of cross-cultural provisions since the theory had its philosophical roots in the USA; sensitivity to differences between Eastern and Western cultures was the issue. Since then, studies conducted in Taiwan and Malaysia (Kohlberg, 1981; Saat, Porter, \& Woodbine, 2008), Hong Kong (Snell, 1996; Ho \& Redfern, 2010), mainland China (Snell \& Tseng, 2001), India (Kracher, Chatterjee, \& Lundquist, 2002) as well as other venues (McDonald \& Pak, 1996) revealed similarities among cultures were more striking than differences; hence, these studies could not totally dispel the universality claim of CMD stages. At the same time, more recent studies looking at guanxi (Au \& Wong, 2000; Ho \& Redfern, 2010) and other cross-cultural comparisons (Karassavidou \& Glaveli, 2007; Vitell \& Patwardhan, 2008; Hilliard, Crudele, Matulich, \& McMurrian, 2011) do not refute previous frameworks but intimate that national cultures are likely to influence the relationship between moral reasoning and behavior. What seems to be at stake is not so much about gender or culture bias per se, but rather the different contexts, environments, and stimuli that nurture the moral 'maturation' process (Jorgensen, 2006).

According to the Kohlbergian sequential process, individuals at lower stages of moral development tend to judge ethical issues in narrower terms because they do not understand the higher stages of moral development; in reverse, individuals at higher stages of moral judgment process the earlier stages but tend to reject such avenues. Kohlberg \& Candee (1984) see a difference between moral judgment and moral behaviour. They hold it is necessary to focus on CMD since it is the single most important and influential factor (albeit not the only one) discovered for moral behaviour. Moral maturity is a long-term and irreversible process whereas moral behaviour is a situational and reversible process. In addition, the higher the level of moral development, the lower the probability of engaging in unethical behaviour under situational pressures (Trevino, 1986).

\subsection{Academic Dishonesty as A Proxy for Unethical Conduct}

Anyone who has spent some time on campus anywhere as a student or as a faculty member knows cheating while taking supervised examinations, copying or obtaining unauthorized help while completing out-of-class assignments (both individual and group) and plagiarism while doing independent work are endemic and allegedly on the rise (McCabe \& Trevino, 1996; Leonard \& Lebrasseur, 2008; Brown, Weible, \& Olmosk, 2010; Burton, Talpade, \& Haynes, 2011). Although it is not possible to generalize a particular study to all institutions and to all countries, the ubiquity of the phenomenon cannot be ignored, particularly since technology and distance learning enhance the opportunities to cheat (Harper, 2006). In numerous American studies, the percentage of student academic misconduct has been estimated as ranging between 13\% and 95\% (McCabe \& Trevino, 1997). The New York Times (Rimer, 2003) published a high profile article citing Rutgers professor McCabe's study in which $38 \%-40 \%$ of surveyed college students admitted to plagiarizing electronic and printed sources without reference. A recent Canadian study conducted by Hughes \& McCabe (2006a) led to similar findings. Fifty-eight percent of high school students, $18 \%$ of undergraduates, and $9 \%$ of graduate students had admitted to cheating of a serious nature (copying from another student, helping another student during a test, using unauthorized crib notes). Moreover, serious plagiarism in written work (copying without reference, fabricating a bibliography, using a paper mill or website source) had been reported by $73 \%$ high school, $53 \%$ undergraduate, and $35 \%$ graduate students.

Since most studies emanate from American publications, findings may give the false impression this is a "US-made" concern. As education becomes more global, the student body is more multi-ethnic and there are more faculty members teaching overseas in countries where academic misconduct may have a different resonance (Chapman \& Lupton, 2004; Heyneman, 2009, 2011). OECD (2010) reported in 2008, there were 3.3 million students studying outside their country of residence, with the bulk of them attending universities in North America, Europe, and Australia. Hence, effective classroom management requires more informed cross-cultural knowledge than the traditional understanding needed for home-grown students, whether classrooms happen to be in Japan or the USA (Diekhoff, LaBeff, Shinohara, \& Yasukawa, 1999), Poland (Lupton, Chapman, \& Weiss, 2000), Hong Kong (Chapman \& Lupton, 2004), Russia (Lupton \& Chapman, 2002), Kazakhstan (Heyneman, 2007), Nigeria (Bakari \& Leach, 2009) or virtually anywhere in the world.

It is widely known that learning approaches used by most Western countries vary drastically from those used in most Eastern countries. In a recent article, Hammer \& Friesen (2011) quoted a Chinese-Canadian student as saying: "In Eastern schools, the teaching is very direct and linear, whereas here (Canada) there are different pathways into getting the concept" (p. 9). Then, he goes on to say his job in China was to study, his job in Canada is to learn. Contrasts do not only exist between East and West as, in the same article, a Venezuelan-Canadian student attested that in his country of origin, homework was optional and students were rarely stressed about grades.

By and large, the Western learning approach is typically guided by a textbook as a point of departure for discussion and structure with the understanding students must connect the dots, fill in the blanks, and use their creativity and critical thinking in assignments. In the East, learning and assessment rest mostly on memorizing the content of a textbook and/or 
the professor's lecture notes with little or no opportunity to participate (Pennycook, 1996; Hayes \&Introna, 2005). In this context, it becomes a sign of respect and reverence for Asian students to use the author's words to such an extent it is extremely difficult for them to express their own opinions on textbook content, to use words other than the author's words, or to criticize an author (Pennycook, 1996; Hayes \& Introna, 2005). On that basis, their educational experience makes them believe it is preferable to use what is already written since they are convinced they cannot improve on the original text (Biggs, 1994; Angelova \& Riazantseva, 1999). The Socratic pedagogical approach and the use of essay writing in most classes of Western institutions put enormous pressure on most overseas students whose previous educational experiences include neither. Their lack of experience in essay writing and their linguistic shortcomings test their time management to the limit; as well, their relative ignorance of local customs, such as a tighter reference system, may lead them to adopt practices accepted at home but not permitted in their new environment (Ashworth, Bannister, \& Thorne, 1997; Carroll, 2002; Flint, Clegg, \& Macdonald, 2006). Given that cultural identity appears to contribute to a coherent personal identity (Schwartz, Zamboanga, \& Weisskirch, 2010), these students need time and assistance to modify their study and assignment habits and to shift to a Western view (since they are studying in the West) where originality and challenge of authority are deemed equally important.

\subsection{Academic Dishonesty and Business Students}

Can students' academic misconduct signal eventual unethical behaviours in the workplace? Hilbert (1985, 1987) investigated nursing students in their final semester and found a positive correlation between academic dishonesty and unethical behaviours in clinical settings. Similar results were reached when Harding, Carpenter, Finelli, \& Passow (2004) compared the decision-making process of engineering students with professional engineers. Are business students made of a different cloth? On the one hand, Jones $(2009$, p 371) posited "there is reason to believe that business students are qualitatively different than non-business students". The field of business may attract students with certain values such as a higher desire for and tolerance to risks, a penchant for making deals, and a propensity for innovative thinking that make them more vulnerable and willing to engage in ethical misbehaviours (Lane, Schaupp, \& Parsons, 1988; White \& Dooley, 1993; Pullen, Ortloff, Casey, \& Payne, 2000; Park, 2003; Jones, 2009). A number of studies point to the fact that business students have lower ethical values than their peers studying other major fields (McCabe \& Trevino, 1997; Caruana, Ramaseshan, \& Ewing, 2000; Smyth \& Davis, 2004).

On the other hand, other studies comparing academic dishonesty of business versus non-business majors reached opposite conclusions or found no significant difference. Brown (1996) found few differences between business students and students of other majors. Others (Meade, 1992; Park, 2003) reported business students were more willing to self-report cases of cheating, followed by engineering and humanities students. This finding raises the question as to whether survey results on academic dishonesty are inherently biased by the social desirability to admit cheating. Another recent study (Iyer \& Eastman, 2006) reached a similar conclusion, although it found significant differences within the business student sample. Students with higher incidents of academic dishonesty were those who had low self-esteem, were more innovative, had a low GPA, or held Greek letter fraternity or sorority membership. Both undergraduate and male students were involved in more incidents of academic dishonesty. Regardless of the results about business versus non-business students, researchers admit there is a genuine misunderstanding of what constitutes academic dishonesty (Park, 2003; Iyer\& Eastman, 2006; Hughes \& McCabe, 2006b). This variation of understanding of student plagiarism is even present among faculty members across disciplines (Flint et al., 2006).

It would appear a degree of discernment is needed when interpreting studies involving business students since they have been a popular choice by researchers due to the obvious connection between business schools and the all-too-frequent scandals in the corporate world (Bay \& Nikitkov, 2011). Based on extensive literature, other variables may have a more determinant effect on academic dishonesty than simply the student's choice of major studies. Buckley, Wiese, \& Harvey (1998) found the best predictors of academic dishonesty were the following and in this order: the probability of being caught and penalized, high hostility and aggression characteristics, and being a man. Other dominant predictors identified included large classes, impersonal relationships with professors, desire to boost GPAs, aspirations to obtain a high-paying job or to gain access to a top graduate school (Pullen et al.,2000; Chapman \& Lupton, 2004), professors' and administrators' professional misconduct, and institutional corruption (Heyneman, 2009, 2011).

\section{Methodology}

This study is the result of a survey conducted with undergraduate business students in eight Ontario (Canada) universities. Business professors were contacted via email and those who agreed to assist with the administration of the questionnaire were sent copies with appropriate instructions so they could have students registered in their course and present the day of the survey respond to the questions. The instructions asked the professor to introduce the survey at the beginning of the class by asking one of their students to volunteer to distribute the questionnaire and collect them once completed. All 
questionnaires (both completed and non-completed) along with the instruction sheet which required the professor to indicate the number of students enrolled in the course and the number present for the survey, were to be placed in a self-addressed stamped-return envelope and mailed back to the authors.

A total of 2533 students were enrolled in the courses selected by the professors for participation in the survey. Only 2010 students were present on the day of the survey and a total of 1617 respondents completed the survey representing an $80.4 \%$ response rate. Some students chose not to answer the survey and others had already completed the survey in another course and therefore were asked not to complete a second survey. The sample was then reduced to 1357 respondents by only including students 18 to 25 years of age (operational definition of emerging adults) registered in a business program. The survey consisted of 54 questions scaled from 1 (very strongly agree) to 7 (very strongly disagree) with a neutral middle point (neither agree nor disagree). In addition, there were 12 categorical socio-demographic questions. The intention behind the scaled questions was to capture students' perceptions and attitudes towards a plethora of academic, social, and personal and value-laden issues, mostly taking place in a student's academic sphere, including social life activities, course assignments, academic and personal assistance from friends and professors, university regulations and academic dishonesty, and commitment to and expectations from studies. Since the survey was covering a vast array of issues, some not related to this particular article on moral reasoning, only a selection of the most pertinent questions were used to develop the statistical model.

[Please insert Table 1 about here]

The authors used a binomial logistic regression for the analysis of the collected data. This logistic regression analysis has a dichotomous $(0,1)$ dependent variable which allows for an analysis between other various responses. As for the independent variables, the software provides for an indicator function within SPSS to compare the different types of responses within the variable. For this analysis, the authors transformed the independent variables to include a two-scaled response: do not agree (0) and agree (1) which allowed for each grouping to be compared to the reference category. This same coding was used for all variables except those gathering socio-demographic information.

From this dataset, the dependent variable is dichotomous ( 0 - Do Not Agree, 1 - Agree) and is based on the question: "My university studies will help me to understand what is morally right and wrong." Meanwhile, the other variables were coded to determine which of the factors were likely to have a positive or negative impact on the dependent variable (expected guidance for moral reasoning). Using the SPSS indicator function, the analysis allows our chosen responses to be compared to all the other possibilities. With this in mind, the software automatically chooses the coded value for the variable of 1(agree) as the reference category which will be compared to those students who do not agree (0).

To determine whether the variable in the equation is significant, the estimated odds ratio was used (shown as Exp (B) in Tables 2 and 3) for which both the upper and lower 95\% confidence interval must be greater than 1 or less than 1 . Using this analysis, the variables that were not statistically significant were screened and removed from Model \#1. Subsequently, the authors ran a second model with the remaining significant variables. In order to verify this test, the Wald's indicator was used for a grouping of one variable to also identify its significance. In econometrics, the square root of the Wald provides a t-test.

\section{Results}

Undergraduate business student $(\mathrm{N}=1357)$ responded to a questionnaire administered in eight Ontario (Canada) universities. The sample comprised $47 \%$ women and $53 \%$ men of which over $97 \%$ of the students had a full-time status. Among the 20 independent variables listed in Model \# 1 (Table 2), only eight (8) remained significant ( $\mathrm{p} \leq .05)$ after running Model \# 2 (Tables 2 and 3). After using the Hosmer and Lemeshow Goodness-of-Fit test, the authors obtained significance levels of 0.976 for Model \# 1 and 0.464 for Model \# 2; therefore, since both results are greater than 0.05 , it was concluded the logistic regression is significant.

\section{[Please insert Table 2 about here]}

[Please insert Table 3 following Table 2]

The purpose of the regression analysis was to identify the significant predictive factors that contributed to the moral integrity development of students (as they perceived it), a concept captured by the following statement: "My university studies will help me to understand what is morally right and wrong." After considering all of the 20 predictors, the model determined that students with the following characteristics and perceptions were more likely to believe that their university studies would be a stimulus to their moral growth:

1) having Canadian citizenship as opposed to a landed immigrant or international student

2) being in upper years of their studies as opposed to the first year 
3) believing their university studies would help them to build self-confidence

4) demonstrating abilities to make independent decisions

5) acquiring skills and competence needed to succeed in life

6) believing their university studies would help them to accept responsibility for themselves

7) believing they can count on other students to help them with their course assignments

8) believing their professors should take the time to discuss the importance of academic honesty.

Given the statistical significance of the above mentioned predictors, evidence exists suggesting students believe and expect their educational experience basket will contain directions for their moral development as previously hypothesized.

\section{Analysis and Discussion of the Results}

\subsection{Background Information}

Among twelve socio-demographic characteristics that were examined, including gender, grade point average, business degree program specialization, residence status (parents, residence, or else), and financial assistance, the results (Table 2) revealed only nationality and year of studies were statistically significant $(\mathrm{p} \leq .05)$. In this case, those who had been Canadian citizens for five years or more as opposed to foreign students (permanent residents without the Canadian citizenship and international students with a study visa) expected their university studies to help them to differentiate right from wrong.

Given the highly different trajectory followed by students who come to Western countries to study $(>75 \%$ originate from Asia) (OECD, 2010), they need considerable orientation and nurturing, institutional as well as societal, to understand the new cultural and ethical dimensions of a wide-open system in which they are allowed to select from a range of choices and make up their own minds. The current result showing that students nationalized as Canadians, have different expectations indicates, at the very least, they may have a better understanding of the objectives and opportunities provided by postsecondary institutions and their resources. Their knowledge of the local system may make them feel more at ease to seek guidance on more personal matters.

Another possible explanation (Vitell \& Patwardham, 2008; Ho \& Redfern, 2010) points in the direction of differences between the Western and Eastern cultures, where the former is highly individualistic and the latter mostly collectivist. Hence, they argue that in the Eastern culture, moral principles and moral absolutes are closely associated with family relationships whereby the elders protect and oversee the well-being of younger members, and in return, children have more deference to their parents. This model is replicated in the work place where superiors are expected to become elders and to show moral leadership by protecting their subordinates. If that is the case, one can easily understand it would be as difficult for Western students newly confronted with a foreign culture to lend trust and loyalty to an unknown approach as it is for Asians to buy into a highly individualistic paradigm for their moral values.

It is also interesting to note that first-year students entertain a different view of their educational experience as they do not expect to be provided with any assistance to shape their moral reasoning. This finding is in keeping with a 10-year summary of research on the various determinants of cheating (McCabe, Trevino, \& Butterfield, 2001) concluding that among a wide range of causes, immaturity and low level of moral development were major causes of academic misconduct. Typically, research results confirm that Canadian high school students cheat more than undergraduate students and that graduate students engage in fewer and less serious types of questionable academic behaviours than undergraduates (Hughes \& McCabe, 2006a). Since first-year students are less likely to believe in their university studies as a lever for improving their moral reasoning, this is an indication of their comparative level of maturity and their struggle to calibrate their new freedom boundaries.

As for other demographic variables namely gender, study and work status, no significant difference was found in this study between males and females, full-time and part-time studies, and the number of hours students worked. There is an extensive volume of findings on these various topics and to say the least, results are neither unanimous nor uni-directional. McCabe \& Trevino (1996) offered the suggestion that gender differences have become narrower in recent years because women are entering formerly male-dominated fields and have to adopt the same competitive spirit and tactics as men, including cheating behaviours. The issue of part-time versus full-time study/work status is another complex situation intertwined with other key factors such as ability, inclusion, motivation, and financial hardship (Broadbridge \& Swanson, 2005; Nonis \& Hudson, 2006). Many university students are of the opinion that university studies are not a full-time occupation; hence, when they are not in class, they are available for work. Can this be blamed on their habits developed in high school or on universities' failure to clearly explain in their first year the commitment required for postsecondary studies? Can this be attributed to students' attitudes that an undergraduate degree has become 
an expected commodity and those who enrol are entitled to receive this reward under just about any circumstance? Can the pressure for high grades and performance blur the academic dishonesty picture and filter attempts at higher levels of moral development where the means does not justify the coveted end?

\subsection{Student's Expectations From the Institution, Peers, Professors, and Educational Experience}

Results indicate students enter university with a minimum set of hidden curriculum expectations which administrative and teaching personnel can easily miss (Table 3). In addition to expecting to receive the knowledge and skills necessary for a successful career, students expect their professors will help them to: develop their self-confidence, develop their capabilities to make independent decisions, and accept personal responsibility for their actions. They also count on other students to help them with their course assignments and their professors to explain and discuss the importance of academic dishonesty. In the last three decades, it has been observed and said many times by researchers and university personnel that idealism among student bodies has been replaced by materialism and careerism (Callahan, 2004). University officials and professors are often at a loss to explain why bright, decent, and generally good character students would take the risk of engaging in questionable academic behaviour and downright academic misconduct when their moral convictions would prevent them from stealing and committing even petty crimes (Willen, 2004). This requires some soul searching not only by questioning students' ethics level but also departmental and institutional ethos. A discussion of both topics may highlight the most salient points.

Survey findings have confirmed the link between emotional intelligence and ethical awareness for undergraduate students (Joseph, Berry, \& Deshpande, 2009; Mesmer-Magnus, Viswesvaran, Deshpande, \& Joseph, 2010). During critical moments, the emotional centre dominates and makes rational behaviour more difficult to achieve. More mature individuals have benefited from years of nurturing and experience within the family, the work place, and the community and have learned to exercise some emotional control, whereas many emerging adults have not yet attained a high level of self-regulation (Zeidner, Matthews, Roberts, \& MacCann, 2003; Kunnanatt, 2008). Much of the core development such as IQ or cognitive intelligence is fully developed by late childhood (Gow, Johnson, Pattie, Brett, Roberts, Starr, \&Deary, 2011). In other words, mathematical, spatial, and language-based abilities are set early; adolescents and emerging adults transform these abilities into skills by interacting with their physical and social environments. Moral reasoning is an example of a complex skill that surfaces after childhood. Cognitive reasoning depends upon both forms of intelligence cognitive intelligence allows the person to work out the implications of one's actions and those of others, and emotional intelligence gives value to these actions through self-monitoring and empathy (Mayer, Salovey, \& Caruso, 2000; Kunnanatt, 2008). From this perspective, lapses in moral judgement by university students deserve some consideration.

On the departmental and institutional side, competing and sometimes conflicting demands, such as financial survival, obsession with rankings, branding, image, searching for balance between teaching and research, and pressures to deliver an ever expanding body of knowledge seem to have produced a shift of values and priorities that may not have been intended. Institutional officials have been saying for a few decades, and rightly so, that education is a big business. We may have lost sight of the fact that a fundamental dimension of education as a business is to develop young adults in formative years by structuring not only their minds and intellect but also by developing their ethical character. Overall, institutional response (by some) to this need has been to insert an ethics course in the curriculum and be satisfied their responsibilities had been discharged; others have not made much progress towards the ethical shortcoming of their students. The quality movement offers a telling story. After WWII, the Japanese in particular were often ridiculed for producing cheap and defect-ridden products until they decided to integrate quality assessment at each production step and make everyone on the assembly line responsible to flag and correct defects. In most other corners of the globe, the quality approach consisted of having a checkpoint at the end of the line to assess the product and catch the defects. After a few decades it became obvious who had won the quality war. Students are asking institutions to help them to grow as persons. The cost of not embedding ethical development at each step of the 'education line' or in most courses may be as high as waiting to spot defects at the end of the 'production' process.

This study found students expect their professors to take the time to discuss the importance of academic dishonesty to guide them in their decision making. This finding is not only a statistically significant finding but one that expresses some hope and freshness of thinking (Kohlberg's level 3, stage 5 or 6 - "what is the right thing to do?") particularly when another related statement on rules of academic dishonesty was found not to help them to develop their ethical conduct (Kohlberg's level 2, stage 4 - "what are the rules and penalties?"). Students are astute observers; examples and advice from a respected professor carry more weight than a lecture. Several studies (McCabe \& Trevino, 2002; Friedman, Fogel, \& Friedman, 2005; Carter \&Punyanunt-Carter, 2006) reported students take a dim view of professors who turn a blind eye to obvious incidents of cheating and engage in unfairness in grading; their actions are seen as less ethical than those of students who engage in academic misconduct. Students who sense their professors are either 
ignoring cheating by their classmates or engaging in unethical and unprofessional conduct (such as favouritism in grading, unpreparedness for lectures, poor class management, and using their position of power in general) are more likely to cheat and to take a negative view of their educational experience as an opportunity for ethical growth.

\section{Implications}

If the parallel between ethical business education situations and subsequent moral reasoning and ethical actions in organizations had not been so much in the public eye over the last few decades, at the very least, it would appear to be intuitive. A student who has no qualms about buying a paper-mill assignment or copying from a website may be more open to receiving or giving a business bribe to gain an advantage. A student being at the receiving end of unfair grading by a teacher may retain the idea that playing favourites is common practice and eventually act the same way towards future employees. A professor who engages in professional misconduct with students may easily give the impression it is normal for managers or individuals in positions of power in the workplace to reward on the basis of privilege rather than achievement. Since these aforementioned cases are all occurrences more or less frequent depending on the country, it is disconcerting to realize the prevalence and frequency of academic dishonesty cases have not provoked a steeper level of collective indignation in academia and led to more formal enquiries as suggested by Hughes \& McCabe (2006a, 2006b).

Academic dishonesty and institutional corruption are not new phenomena; the globalization of education has only made them more pervasive, more frequent, and more exposed. Countries that are known to be permeated with unethical practices across most sectors of their economy have also lost the trust of their own citizens and the world on their willingness to propagate universal values of fairness and impartiality through their educational institutions. When a system operates on 'irregularities', personal ethics becomes entirely disconnected from enforced localized norms (Heyneman, 2011). This is particularly troubling since education is the linchpin of a nation's social fabric.

Most professors engage in university teaching to make a difference in the intellectual development of young minds. When they first encounter students who breach their trust with academic dishonesty, they realize their own academic training has not quite prepared them to deal with the misconduct of their students. What to do? They quickly learn that it would be much easier to do nothing: no confrontation with the students, no paper work, no meeting with the Department Chair or Dean, no appeal, no nasty comments on www.ratemyprofessors.com, in brief, no burden. Unless they operate at the preconventional level of Kohlberg's theory (Stage 1 - "what are my own interests?" or Stage 2 - "if I do nothing, will my reputation be damaged?"), they will reason they must do something in the name of academic integrity, justice towards non-cheating students, and trust they will be supported by the system. Instinctively they will investigate the policies in place against academic dishonesty (Kohlberg's stages 3 and 4 - "what are the rules and penalties?). It is unfortunate to say that, if a professor has to enquire about the processes and sanctions in place, it is a clear indication the deterrence system is weak and invisible. It also means few students would have any knowledge of the rules of engagement if they yielded to unethical conduct, let alone an understanding of what is considered border line unethical conduct versus hard core cheating.

Attempting to run an ethical classroom and/or organization in education is not very different from other kinds of endeavours. This process can be summarized in four key steps:

1) Educate, define, and interpret what (un)ethical (mis)conduct is about. This will likely begin with a basic business ethics course in the curriculum to discuss main ethical moral philosophies and models, and apply them to practical business situations. Since formal education has been proven to be "the" dominant predictor of CMD and ethical education has also been found to influence behavior, the cost of ignorance may be too enormous. The pedagogical case study approach, widely used in the business education curriculum, offers contextual opportunities to ally functional knowledge with softer skills. Students long for their moral imagination to be stimulated. As their analytical skills are built in functional areas, the various ethical issues associated with principles, options, actions, and consequences have to be integrated in decision-making frameworks. Albeit challenging, the case approach allows a business school to focus on the student as a person with leadership potential.

2) Put preventative measures in place. This is where the institution's/academic unit's ethos and the individual instructor's stamp come into play. The literature informs us the best deterrent to academic dishonesty is the fear of being caught, punished, and shamed (McCabe et al., 2001; Clement, 2001; Levy \&Rakovski, 2006). Institutions that have embedded academic codes of ethics are known to have reduced cheating, particularly those who have used the admission process to obtain a personal commitment to adhere to the code of ethics from students entering the university. Academic units should make sure their particular code of ethics is visible, easily accessible, and specific enough so that students who fail to live up to their commitment understand the consequences of transgressing ethical conduct. Such visibility could even include publishing the names of cheaters (as done with DUI's) and 
having open (any student can attend) committee hearings for academic misconduct cases to act as a deterrent for this unacceptable behaviour. A caveat: codes of ethics that are seen as 'just policing' are not likely to work.

As the classroom leader and manager, the instructor has to be seen as such and also has to set the pace. Here are a few practical suggestions put forth by Levy \& Rakovski (2006): a) make a clear statement about academic dishonesty in your course syllabus; b) give different exams and paper assignments each semester/year; c) make a few versions of the same exam particularly when there are multiple-choice questions; d) prohibit all technology during an exam; e) go out of your way to spell out the rules of academic dishonesty particularly when you have a cross-cultural audience, and invite anyone who needs clarifications to see you; f) introduce yourself as a zero tolerance professor; and g) take action when the trust is violated.

3) Determine the bodies and/or authorities who will review alleged cases. Each institution and academic unit should have a series of actions in place to make sure that due process is fair to both parties and void of inconsistencies. It is critical that the various players, such as students, faculty members, and the institution have a common understandingof how plagiarism and cheating are defined (Flint et al., 2006). This information must be part and parcel of any academic dishonesty documentation available via a website or written documentation upon request.

4) Spell out what the sanctions will be. A recent study (Hilliard et al., 2011) investigating the various penalties in a sample of institutions located in Asia, South Pacific, Europe, Canada, and Latin America revealed the punishment options ranged broadly. Among many others, they included a passive attitude, a warning to the student, resubmission of the assignment, a zero grade, permanent notations on student records, and expulsion from the university. Realistically, the severity of the penalties should be based on the degree of academic dishonesty and whether the student is a first-time or repeat offender.

\section{Concluding Remarks}

This study was an attempt to investigate whether business students had any appetite for some moral direction while in school and where they were likely to seek such support. A few variables were found statistically significant as predictors of their desire and welcoming attitude towards being guided in their moral growth. Results are discussed in relationship with CMD theories, using academic dishonesty as a proxy for unethical misconduct in school and in the work place. Although research indicates there is a link between moral reasoning and moral action, this association is neither linear nor perfect as studies have shown. If nothing else, it suggests "we must return to an earlier time when the development of ethical character was a core component of leadership training" (Cunningham, 2011, p. 13). Shaping the emerging adult into a leader, in terms of ethical and professional conduct, means helping the university student achieve an integration of his/her cognitive and emotional intelligences. As educators, we need to better understand our students who are not mature, but rather emerging adults eager to exercise their adulthood.

We also need to reflect on what effects the overly competitive nature of modern Universities may have on students' choices to act 'immorally'. How do we increase the likelihood of business students to act more ethically and to have fewer lapses of judgment? There is no magic wand. As Christensen, Barnes, \& Rees (2007) expressed so well, institutions and educators must demonstrate their moral resolve by providing ethical frameworks in the curriculum and leading by example.

In subsequent studies on a similar topic, it may be of interest to segregate business students into functional areas such as accounting, marketing, human resources, consumer behavior, and others to compare attitudes and perceptions regarding moral reasoning and academic conduct. A test (first year) and re-test (fourth year) experimental study with the same students would likely yield even more informative results on their moral evolution while in school.

\section{References}

AACSB International - The Association to Advance Collegiate Schools of Business. (2011). Eligibility procedures and accreditation standards for business accreditation. [Online] Available: www.aacsb.edu/accreditation/business/AACSBSTANDARDS.pdf

Allen, W. R., Bacdayan, P., Berube Kowalski, K., \& Roy, M. H. (2005). Examining the impact of ethics training on business student values, Education \& Training, 47(2/3), 170-182. http://dx.doi.org/10.1108/00400910510592220

Allmon, D.E., Page, D., \& Roberts, R. (2000). Determinants of perceptions of cheating: Ethical orientation personality and demographics, Journal of Business Ethics, 23(4), 411-422. http://dx.doi.org/10.1023/A:1006087104087

Angelova, M., \& Riazantseva, A. (1999). If you don't tell me, how can I know? A case study of four international students learning to write the U.S. way, Written Communication, 16, 491-525. http://dx.doi.org/10.1177/0741088399016004004 
Arnett, J. (2000). Emerging adulthood: A theory of development from the late teens through the twenties, American Psychologist, 55, 469-480. http://dx.doi.org/10.1037/0003-066X.55.5.469

Arnett, J. (2004). Emerging adulthood: The winding road from the late teens through the twenties. New York: Oxford University Press.

Arnett, J. (2007a). Suffering, selfish, slackers? Myth and reality about emerging adults, Journal of Youth Adolescence, 36, 23-29. http://dx.doi.org/10.1007/s10964-006-9157-z

Arnett, J. (2007b). Adolescence and emerging adulthood - A cultural approach. New Jersey: Pearson Prentice Hall.

Ashworth, P., Bannister, P., \& Thorne, P. (1997). Guilty in whose eyes: University students' perception of cheating and plagiarism, Studies in Higher Education, 22, 187-203. http://dx.doi.org/10.1080/03075079712331381034

Au, A. K. M., \& Wong, D. (2000). The impact of guanxi on the ethical decision-making process of auditors - An exploratory study on Chinese CPAs in Hong Kong, Journal of Business Ethics, 28(November), 87-93. http://dx.doi.org/10.1023/A:1006117021164

Bakari, S. \& Leach, F. (2009). I invited her to my office: Normalizing sexual violence in a Nigerian College of Education. In S. P. Heyneman (ed.), Buying your way into heaven - Education and corruption in international perspective. Rotterdam/Taipei: Sense Publishers, 9-21.

Bay, D., \& Nikitkov, A. (2011). Subjective probability assessments of the incidence of unethical behavior: The importance of scenario respondent fit, Business Ethics: A European Review, 20(1), 1-11.

Beck, L., \& Ajzen, I. (1991). Predicting dishonest actions using the theory of planned behavior, Journal of Research in Personality, 25(3), 285-301. http://dx.doi.org/10.1016/0092-6566(91)90021-H

Biggs, J. (1994). Asian learners through Western eyes: An astigmatic paradox, Australian and New Zealand Journal of Vocational Educational Research, 2(2), 40-63.

Broadbridge, A., and Swanson, V. (2005). Earning and learning: How term-time employment impacts on students' adjustment to university life, Journal of Education and Work, 18(2), 235-249. http://dx.doi.org/10.1080/13639080500086008

Brown, B.S. (1996). A comparison of the academic ethics of graduate business education and engineering students, College Student Journal, 30,294-301.

Brown, B. S., Weible, R. J., \& Olmosk, K. (2010). Business school deans on student academic dishonesty: A survey, College Student Journal, 44(2): 299-308.

Buckley, M. R., Wiese, D. S., \& Harvey, M. G. (1998). An investigation into the dimensions of unethical behavior, Journal of Education for Business, 73,284-290. http://dx.doi.org/10.1080/08832329809601646

Burton, J. H., Talpade, S., \& Haynes, J. (2011). Religiosity and test-testing ethics among business school students, Journal of Academic and Business Ethics, 4 (July), 1-8.

Callahan, D. (2004). The teaching culture: Why more Americans are doing wrong to get ahead. Orlando, Florida: Harcourt, Inc.

Carroll, J. (2002). Suggestions for teaching international students more effectively - Learning and teaching briefing papers series. Oxford: Oxford Brookes University.

Carter, S. L., \& Punyanunt-Carter, N. M. (2006). Acceptability of treatments for cheating in the college classroom, Journal of Instructional Psychology, 33(3), 212-216.

Caruana, A., Ramaseshan, B., \& Ewing, M. T. (2000). The effect of anomie on academic dishonesty among university students, The International Journal of Educational Management, 14 (1), 23-29. http://dx.doi.org/10.1108/09513540010310378

Cavanagh, G. F., Moberg, D. J., \& Velasquez, M. (1981). The ethics of organizational politics, Academy of management review, 6, 363-374.

Cavico, F.J., \& Mujtaba, B. G. (2009). The state of business schools, business education, and business ethics, Journal of Academic and Business Ethics, 2, 1-18.

Chapman, K. J., \& Lupton, R. A. (2004). Academic dishonesty in a global educational market: A comparison of Hong Kong and American university business students, The International Journal of Educational Management, 18(6/7), 425-435. http://dx.doi.org/10.1108/09513540410563130 
Christensen, D., Barnes, J. N., and Rees, D. A. (2007). "Developing Resolve to Have Moral Courage: A Field Comparison of Teaching Methods", Journal of Business Ethics Education (4), pp. 79-96.

Clement, M.J. (2001). Academic dishonesty: To be or not to be? Journal of Criminal Justice Education, 12(2), 253-270.http://dx.doi.org/10.1080/10511250100086101

Cunningham, P. (2011). Recognizing the value of ethics, National Post, Toronto: Post Media Network, April 13.

Diekhoff, G. M., LaBeff, E. E., Shinohara, K., \& Yasukawa, H. (1999). College cheating in Japan and the United States, Research in Higher Education, 40(3): 343-353. http://dx.doi.org/10.1023/A:1018703217828

Ferrell, O. C., Gresham, L. G, \& Fraedrich, J. (1989). A synthesis of ethical decision models for marketing, Journal of Macromarketing, 9, 55-64. http://dx.doi.org/10.1177/027614678900900207

Flint, A., Clegg, S., \& Macdonald, R. (2006). Exploring staff perceptions of student plagiarism, Journal of Further and Higher Education, 30(2), 145-156. http://dx.doi.org/10.1080/03098770600617562

Frederiksen, C.S. (2010). The relationship between policies concerning corporate social responsibility (CSR) and philosophical moral theories - An empirical investigation, Journal of Business Ethics, 93(3), 357-371. http://dx.doi.org/10.1007/s10551-009-0226-6

Friedman, H. H., Fogel, J., \& Friedman, L. W. (2005). Student perceptions of the ethics of professors, Electronic Journal of Business Ethics and Organization Studies, 10(2), 10-15.

Gilligan, C. (1998). Remembering Larry, Journal of Moral Education, 27(2), 125-140. http://dx.doi.org/10.1080/0305724980270201

Goolsby, J. R., \& Hunt, S. D. (1992). Cognitive moral development and marketing, Journal of Marketing, 56, 55-68. http://dx.doi.org/10.2307/1252132

Gow, A, Johnson, W., Pattie, A., Brett, C., Roberts, B., Starr, J., \& Deary, I. (2011). Stability and change in intelligence from age 11 to ages 70, 79, and 87: The Lothian birth cohorts of 1921 and 1936, Psychology and Aging, 26(1), 232-240. http://dx.doi.org/10.1037/a0021072

Hammer, K. and Friesen, J. (2011). The myth of the brainy immigrant, Toronto, The Globe and Mail, January 22.

Harding, T. S., Carpenter, D. D., Finelli, C. J., \& Passow, H. J. (2004). Does academic dishonesty relate to unethical behavior in professional practice? An exploratory study, Science and Engineering Ethics, 10(2), 311-324. http://dx.doi.org/10.1007/s11948-004-0027-3

Harper, M. G. (2006). High tech cheating, Nurse Education in Practice, 6, 364-371. http://dx.doi.org/10.1016/j.nepr.2006.07.008

Harris, H. (2008). Promoting ethical reflection in the teaching of business ethics, Business Ethics: A European Review, 17, 379-390.

Hayes, N., \& Introna, L. D. (2005). Cultural values, plagiarism, and fairness: when plagiarism gets in the way of learning, Ethics and Behavior, 15(3), 213-231. http://dx.doi.org/10.1207/s15327019eb1503_2

Heyneman, S. P. (2007). Three universities in Georgia, Kazakhstan and Kyrgyzstan: The struggle against corruption and for social cohesion, Prospects, 37, 305-318. http://dx.doi.org/10.1007/s11125-008-9037-2

Heyneman, S. P. (2009). Education corruption in international perspective: An introduction. In S. P. Heyneman (ed.), Buying your way into heaven - Education and corruption in international perspective. Rotterdam/Taipei: Sense Publishers, 1-8.

Heyneman, S. P. (2011). The concern with corruption in higher education. In T. B. Gallant (ed.), Creating the ethical academy: A systems approach to understanding misconduct and empowering change in higher education. Routledge, Taylor \& Francis Group.

Hilbert, G. (1985). Involvement of nursing students in unethical classroom and clinical behaviors, Journal of Professional Nursing, 1(4), 230-234.http://dx.doi.org/10.1016/S8755-7223(85)80160-5

Hilbert, G. (1987). Academic fraud: Prevalence, practices, and reasons, Journal of Professional Nursing, 3(1), 39-45. http://dx.doi.org/10.1016/S8755-7223(87)80026-1

Hilliard, H., Crudele, T., Matulich, E., \& McMurrian, R. (2011). International educational ethics: Asia, South Pacific, Europe, Canada and Latin America, Journal of Academic and Business Ethics, 3, 1-10. 
Ho, F.N., Vitell, S.J., Barnes, J.H., \& Desborde, R. (1997). Ethical correlates of role conflict and ambiguity in marketing: The mediating role of cognitive moral development, Journal of the Academy of Marketing Science, 25(2), 117-126. http://dx.doi.org/10.1007/BF02894347

Ho, C., \& Redfern, K. A. (2010). Consideration of the role of guanxiin the ethical judgments of Chinese managers, Journal of Business Ethics, 96, 207-221. http://dx.doi.org/10.1007/s10551-010-0459-4

Hooker, J. (2004). The case against business ethics education: A study in bad arguments, Journal of Business Ethics Education, 1(1), 75-88.

Hughes, J. M. C., \& McCabe, D. L. (2006a). Academic misconduct within higher education in Canada, The Canadian Journal of Higher Education, 36(2), 1-21.

Hughes, J. M. C., \& McCabe, D. L. (2006b). Understanding academic misconduct, The Canadian Journal of Higher Education, 36(1), 49-63.

Hunt, S. D., \& Vitell, S. J. (2006). A general theory of marketing ethics: A revision and three questions, Journal of Macromarketing, 26(2), 143-153. http://dx.doi.org/10.1177/0276146706290923

Hunt, S. D., \& Vitell, S. J. (1993). The general theory of marketing ethics: A retrospective and revision. In N. C. Smith \& J. A. Quelch (eds.), Ethics in marketing. Homewood, IL: Irwin, 775-784.

Hunt, S. D., \& Vitell, S. J. (1986), A general theory of marketing ethics, Journal of Macromarketing, 6(Spring), 5-15. http://dx.doi.org/10.1177/027614678600600103

Iyer, R., \& Eastman, J. K. (2006). Academic dishonesty: Are business students different from other college students? Journal of Education for Business, November/December, 101-110. http://dx.doi.org/10.3200/JOEB.82.2.101-110

Jones, T. M. (1991). Ethical decision making by individuals in organizations: An issue- contingent model, Academy of Management Review, 16, 366-395.

Jones, D. A. (2009). A novel approach to business ethics training: Improving moral reasoning in just a few weeks, Journal of Business Ethics, 88,367-379. http://dx.doi.org/10.1007/s10551-008-9969-8

Jorgensen, G. (2006). Kohlberg and Gilligan: duet or duel? Journal of Moral Education, 35(2), 179-196. http://dx.doi.org/10.1080/03057240600681710

Joseph, J., Berry, K., \& Deshpande, S. (2009). Impact of emotional intelligence and other factors on perception of ethical behavior of peers, Journal of Business Ethics, 89(4), 539-546. http://dx.doi.org/10.1007/s10551-008-0015-7

Karassavidou, E., \& Glaveli, N. (2007). Ethical orientations of future Greek business people: Is anomia responsible for deviant ethical attitudes? Business Ethics: A European Review, 16(2), 114-123. http://dx.doi.org/10.1111/j.1467-8608.2007.00482.x

Kujala, J., Lämsä, A.M., \& Penttila, K. (2011). Managers' moral decision-making patterns over time: A multidimensional approach, Journal of Business Ethics, 100, 191-207. http://dx.doi.org/10.1007/s10551-010-0467-4

Kohlberg, L. (1969). Handbook of socialization: Theory and research. Chicago: Rand-McNally.

Kohlberg, L. (1976). Moral stages, moralization: The cognitive developmental approach. In T. Lickona (ed.), Moral development and behavior. New York: Holt, Rinehart, Winston.

Kohlberg, L. (1981). Essays on moral development: The philosophy of moral development, Vol. 1, San Francisco, California: Harper and Row.

Kohlberg, L., \& Candee, D. (1984). The relationship of moral judgment to moral action. In W. M. Kurtines, \& J. L. Gewirtz (eds). Morality, moral behavior and moral development. NY: Wiley, 52-73.

Kracher, B., Chatterjee, A., \& Lundquist, A. R. (2002). Factors related to the cognitive moral development of business students and business professionals in India and the United States: Nationality, education, sex and gender, Journal of Business Ethics, 35, 255-268. http://dx.doi.org/10.1023/A:1013859404733

Kunnattnat, J. (2008). Emotional intelligence: theory and description, Career Development International, 13(7), 614-629. http://dx.doi.org/10.1108/13620430810911083

Lane, M. S., Schaupp, D., \& Parsons, B. (1988). Pygmalion effect: An issue for business education and ethics, Journal of Business Ethics, 7, 223-229. http://dx.doi.org/10.1007/BF00381872

Levy, E. S., \& Rakovski, C. C. (2006). Academic dishonesty: A zero tolerance professor and student registration choices, Research in Higher Education, 47(6), 735-754. http://dx.doi.org/10.1007/s11162-006-9013-8 
Leonard, V., \& Lebrasseur, R. (2008). Individual assignments and academic dishonesty - exploring the learning conundrum, The Australian Educational Researcher 35 (1): 37-56. http://dx.doi.org/10.1007/BF03216874

Lind, G. (2008). Moral judgment test (MJT). [Online] Available: http://www.uni-konstanz.de/ag-moral/mut/mjt-engl.htm.

Lounsbury, J. W., Huffstetler, B. C., Leong, F. T., \& Gibson, L. W. (2005). Sense of identity and collegiate academic achievement, Journal of College Student Development, 46(5), 501-514. http://dx.doi.org/10.1353/csd.2005.0051

Low, M., Davey, H., \& Hooper, K. (2008). Accounting scandals, ethical dilemmas and educational challenges, Critical Perspectives on Accounting, 19, 222-254. http://dx.doi.org/10.1016/j.cpa.2006.05.010

Lupton, R. A., Chapman, K. J., \& Weiss, J. E. (2000). A cross-national exploration of business students' attitudes, perceptions, and tendencies toward academic dishonesty, Journal of Education for Business,March/April, 231-235. http://dx.doi.org/10.1080/08832320009599020

Lupton, R. A., \& Chapman, K. J. (2002). Russian and American college students' attitudes, perceptions and tendencies towards cheating, Educational Research, 44(1), 17-27. http://dx.doi.org/10.1080/00131880110081080

Mayer, J., Salovey, P., \& Caruso, D. (2000). Models of emotional intelligence. In R.Seternberg (Ed.), Handbook of intelligence $\left(2^{\text {nd }}\right.$ ed., 396-420). New York: Cambridge University Press.

McCabe, D. L., \& Trevino, L. K. (1996). What we know about cheating in college, Change, January/February, 29-33.

McCabe, D. L., \& Trevino, L. K. (1997). Individual and contextual influences on academic dishonesty: A multicampus investigation, Research in Higher Education, 38(3), 379-396. http://dx.doi.org/10.1023/A:1024954224675

McCabe, D. L., Trevino, L. K., \& Butterfield, K. D. (2001). Cheating in academic institutions: A decade of research, Ethics \& Behavior, 11(3), 219-232. http://dx.doi.org/10.1207/S15327019EB1103_2

McCabe, D. L., \& Trevino, L. K. (2002). Honesty and honor code, Academe, 88(1), 37-41. http://dx.doi.org/10.2307/40252118

McDonald, G.M, \& Pak, P.C. (1996). It's all fair in love, war, and business: Cognitive philosophies in ethical decision making, Journal of Business Ethics, 15(September), 973-996. http://dx.doi.org/10.1007/BF00705577

McLafferty, C.L., \& Foust, K.M. (2004). Electronic plagiarism as a college instructor's nightmare - Prevention and detection, Journal of Education for Business, 79,186-189. http://dx.doi.org/10.3200/JOEB.79.3.186-190

Meade, J. (1992). Cheating: Is academic dishonesty par for the course?,Prism, 1(7), 30-32.

Mesmer-Magnus, J., Viswesvaran, C. Deshpande, S. \& Joseph, J. (2010). Emotional intelligence, individual ethicality, and perceptions that unethical behavior facilitates success, Revista de PsicologiadelTrabajo y de Las Organizaciones, 26(1), 35-45. http://dx.doi.org/10.5093/tr2010v26n1a3

Neubaum, D. O., Pagell, M., Drexler, Jr., J. A., McKee-Ryan, F. M., \& Larson, E. (2009). Business education and its relationship to student personal moral philosophies and attitudestoward profits: An empirical response to critics, Journal of Management Learning \&Education, 8 (1), 9-24.

Nonis, S. A., \& Hudson, G. I. (2006). Academic performance of college students: Influence of time spent studying and working, Journal of Education for Business, January/February, 151-159. http://dx.doi.org/10.3200/JOEB.81.3.151-159

OECD. (2010). Education at a glance 2010 - OECD Indicators. Paris, France: OECD Publishing.

O'Fallon, M. J., \& Butterfield, K. D. (2005). A review of the empirical ethical decision-making literature: 1996-2003, Journal of Business Ethics, 59, 375-413. http://dx.doi.org/10.1007/s10551-005-2929-7

Park, C. (2003). In other (people's) words: Plagiarism by university students - Literature and lessons, Assessment \& Evaluation in Higher Education, 28, 471-488. http://dx.doi.org/10.1080/02602930301677

Pennycook, A. (1996). Borrowing others' words: Text, ownership, memory and plagiarism, TESOL Quarterly, 30,210-230. http://dx.doi.org/10.2307/3588141

Piaget, J. (1932). The moral judgment of the child. London: Kegan Paul.

Pullen, R., Ortloff, V., Casey, S., \& Payne, J. B. (2000). Analysis of academic misconduct using unobtrusive research: A study of discarded cheat sheets, College Student Journal, 3, 616.

Reed, D. C. (1997). Following Kohlberg: Liberalism and the practice of democratic community. Notre Dame, Indiana: University of Notre Dame Press. 
Rest, R., Thoma, S. J., Moon, Y. L., \& Getz, I. (1986). Moral judgment, behavior, decision making, and attitudes. In R. Rest (ed.), Moral development: Advances in research and theory. New York: Praeger.

Rest, J., \& Deemer, D. (1986). Life experience and developmental pathways. In R. Rest (ed.), Moral development: Advances in research and theory. New York: Praeger.

Rest, J. (1986). Moral development: Advances in research and theory. New York: Praeger.

Rest, J. (1988). Can ethics be taught in professional schools? Easier said than done, Psychological research, Winter issue, 23-24.

Rest, J., \& Narvaez, D. (1994). Moral development in the professions: Psychology and applied ethics. Hillsdale, New Jersey: Lawrence Erlbaum Associates Publishers.

Rest, J., Narvaez, D., Bebeau, M. J., \& Thoma, S. J. (1999). Postconventional moral thinking: A neo-Kohlbergian approach. Mahwah, NJ: Lawrence Erlbaum Associates.

Rimer, S. (2003). A campus fad that's being copied: Internet plagiarism, New York Times, September 3.

Saat, M. M., Porter, S., \& Woodbine, G. (2010). An exploratory study of the impact of Malaysian ethics education on ethical sensitivity, Journal of Business Ethics Education, 7, 39-62.

Schwartz, S., Zamboanga, B., \& Weisskirch, R. (2010). The relationships of personal and cultural identity to adaptive and maladaptive psychosocial functioning in emerging adults, Journal of Social Psychology, 150(1), 1-33. http://dx.doi.org/10.1080/00224540903366784

Sims, R.L. (1993). The relationship between academic dishonesty and unethical business practices, Journal of Education for Business, 69(2), 207-211. http://dx.doi.org/10.1080/08832323.1993.10117614

Smith, J., \& Dubbink, W. (2011). Understanding the role of moral principles in business ethics: A Kantian perspective, Business Ethics Quarterly, 21(2), 205-231.

Smyth, M. L., \& Davis, J. R. (2004). Perceptions of dishonesty among 2-year college students: Academic versus business situations, Journal of Business Ethics, 51(1), 63-73. http://dx.doi.org/10.1023/B:BUSI.0000032347.79241.3c

Snell, R. S. (1996). Complementing Kohlberg: Mapping the ethical reasoning used by managers for their own dilemma cases, Human Relations, 49(January), 23-49. http://dx.doi.org/10.1177/001872679604900102

Snell, R. S., \& Tseng, C. S. (2001). Ethical dilemmas of relationship building in China, Thunderbird InternationalBusiness Review, 43(Mar/Apr), 171-200. http://dx.doi.org/10.1002/tie.1

Thoma, S. J. (1985). On improving the relationship between moral reasoning and external criteria: The utilizer/nonutilizer dimension, unpublished doctoral dissertation. University of Minnesota.

Trevino, L. K. (1986). Ethical decision making in organizations: a person-situation interactionist perspective, Academy of Management Review, 11(3), 601-617.

Trevino, L.K. (1992). Moral reasoning and business ethics: Implications for research, education, and management, Journal of Business Ethics, 11, 445-459. http://dx.doi.org/10.1007/BF00870556

Vitell, S.J., \& Patwardhan, A. (2008). The role of moral intensity and moral philosophy in ethical decision making: A cross-cultural comparison of China and the European Union, Business Ethics: A European Review, 17(2), 196-209.

Warnell, J. M. (2010). An undergraduate business ethics curriculum: Learning and moral development outcomes, Journal of Business Ethics Education, 7, 63-84.

White, C S., \& Dooley, R. S. (1993). Ethical or practical: An empirical study of students' choices in simulated business scenarios, Journal of Business Ethics, 12, 643-651. http://dx.doi.org/10.1007/BF01845903

Willen, M. S. (2004). Reflections on the cultural climate of plagiarism, Liberal Education, Fall, 55-58.

Wimbush, J.C. (1999). The effect of cognitive moral development and supervisory influence on subordinates ethical behavior, Journal of Business Ethics, 18, 383-395. http://dx.doi.org/10.1023/A:1006072231066

Zeidner, M., Matthews, G. Roberts, R., \& MacCann, C. (2003). Development of emotional intelligence: Towards a multi-level investment model, Human Development, 46, 69-96. http://dx.doi.org/10.1159/000068580 
Table 1. List of independent variables

\begin{tabular}{|c|c|}
\hline \multicolumn{2}{|c|}{ Background Information } \\
\hline Q1 & Gender \\
\hline Q2 & Citizenship \\
\hline Q3 & Study Status (Part Time or Full Time) \\
\hline Q4 & Year of Studies \\
\hline Q5 & Work Status \\
\hline \multicolumn{2}{|c|}{ Expectations from the Institution } \\
\hline Q6 & I am sincerely interested in my courses. \\
\hline Q7 & My university education has given me useful skills. \\
\hline Q8 & I can count on most of my professors to help build my self-confidence. \\
\hline Q9 & My university studies will help me to make independent decisions. \\
\hline Q10 & The marks I obtain in my university studies are important for my future. \\
\hline Q11 & $\begin{array}{l}\text { My university studies will give me the skills and competence that I need } \\
\text { to succeed in life. }\end{array}$ \\
\hline Q12 & My university studies will help me to accept responsibility for myself. \\
\hline Q13 & I can count on other students to help me with my course assignments. \\
\hline \multicolumn{2}{|c|}{ Expectations from Professors } \\
\hline Q14 & $\begin{array}{l}\text { Most of my professors encourage students to discuss an individual } \\
\text { assignment and exchange ideas. }\end{array}$ \\
\hline Q15 & $\begin{array}{l}\text { Most of my professors require that student complete the individual } \\
\text { assignments without help from anyone. }\end{array}$ \\
\hline Q16 & $\begin{array}{l}\text { Most of my professors are vague about whether students can help each } \\
\text { other on an individual assignment. }\end{array}$ \\
\hline Q17 & $\begin{array}{l}\text { Most of my professors take the time to discuss the importance of } \\
\text { academic honesty. }\end{array}$ \\
\hline Q18 & $\begin{array}{l}\text { Most of my professors give me advice and guidance to solve personal } \\
\text { problems involving my university studies. }\end{array}$ \\
\hline Q19 & $\begin{array}{l}\text { Most of my professors are available to help me on my course } \\
\text { assignments. }\end{array}$ \\
\hline Q20 & $\begin{array}{l}\text { Most of my professors clearly explain the university regulations covering } \\
\text { academic dishonesty. }\end{array}$ \\
\hline
\end{tabular}


Table 2. Results of Models \# 1 and \# 2

\begin{tabular}{|c|c|c|c|c|c|c|c|c|c|}
\hline \multirow[t]{3}{*}{ Variables } & \multirow[t]{3}{*}{$\begin{array}{l}\text { Coded } \\
\text { Values } \\
\end{array}$} & \multicolumn{4}{|c|}{ Model \#1 } & \multicolumn{4}{|c|}{ Model \#2 } \\
\hline & & \multirow[b]{2}{*}{ Beta } & \multirow{3}{*}{$\begin{array}{c}\text { Wald } \\
38.919\end{array}$} & \multicolumn{2}{|c|}{$\begin{array}{l}\text { 95.0\% C.I. for } \\
\text { EXP(B) }\end{array}$} & \multirow[b]{2}{*}{ Beta } & \multirow[b]{2}{*}{ Wald } & \multicolumn{2}{|c|}{$\begin{array}{l}\text { 95.0\% C.I. for } \\
\text { EXP(B) } \\
\end{array}$} \\
\hline & & & & Lower & Upper & & & Lower & Upper \\
\hline Constants & & 1.541 & & & & 1.179 & 45.893 & & \\
\hline \multicolumn{10}{|c|}{ Background Information } \\
\hline $\begin{array}{l}\text { 1. Gender } \\
\text { Ref. }\end{array}$ & $\begin{array}{l}\text { Male (0) } \\
\text { Female (1) }\end{array}$ & -.122 & .857 & .684 & 1.146 & & & & \\
\hline \multirow[t]{2}{*}{ 2. Citizenship** } & $\begin{array}{l}\mathrm{CDN \dagger} \\
5+\mathrm{yrs}(0)\end{array}$ & .606 & 7.869 & 1.200 & 2.802 & .630 & 9.140 & 1.877 & 1.248 \\
\hline & $\begin{array}{l}\text { Not CDN } \\
5+\mathrm{yrs}(1)\end{array}$ & & & & & & & & \\
\hline $\begin{array}{l}\text { 3. Study Status } \\
\text { Ref. }\end{array}$ & $\begin{array}{l}\text { Part-time(0) } \\
\text { Full-time(1) }\end{array}$ & .184 & .197 & .533 & 2.715 & & & & \\
\hline \multirow{3}{*}{ 4. Yr of Study** } & $1 \mathrm{st}(1)$ & .636 & 15.965 & 1.383 & 2.581 & .540 & 13.245 & 1.716 & 1.283 \\
\hline & 2nd (2) & .444 & 4.440 & 1.031 & 2.355 & .374 & 3.444 & 1.453 & .979 \\
\hline & $3 \operatorname{rd}(3)$ & .183 & .709 & .784 & 1.840 & .143 & .458 & 1.153 & .763 \\
\hline Ref. & 4th (4) & & & & & & & & \\
\hline $\begin{array}{l}\text { 5. Work Status } \\
\text { Ref. }\end{array}$ & $\begin{array}{l}\text { No }(0) \\
\text { Yes }(1)\end{array}$ & -.106 & .138 & .686 & 1.179 & & & & \\
\hline
\end{tabular}

$\dagger$ Canadian citizenship $\quad * * \leq .05$ 
Table 3. Results of Models \# 1 and \# 2

\begin{tabular}{|c|c|c|c|c|c|c|c|c|c|}
\hline Variables & Coded & \multicolumn{4}{|c|}{ Model \#1 } & \multicolumn{4}{|c|}{ Model \#2 } \\
\hline & & \multirow[b]{2}{*}{ Beta } & \multirow[b]{2}{*}{ Wald } & \multicolumn{2}{|c|}{$\begin{array}{l}\text { 95.0\% C.I. for } \\
\text { EXP(B) }\end{array}$} & \multirow[b]{2}{*}{ Beta } & \multirow{3}{*}{$\begin{array}{l}\text { Wald } \\
45.893 \\
\end{array}$} & \multicolumn{2}{|c|}{$\begin{array}{l}\text { 95.0\% C.I. for } \\
\text { EXP(B) }\end{array}$} \\
\hline & & & & Lower & Upper & & & Lower & Upper \\
\hline Constants & & 1.541 & 38.919 & & & 1.179 & & & \\
\hline \multicolumn{10}{|c|}{ Expectations from the Institution } \\
\hline $\begin{array}{l}\text { 6. Course Interest } \\
\text { Ref. }\end{array}$ & $\begin{array}{l}\operatorname{DNA}(0) \dagger \\
\text { Agree }(1)\end{array}$ & .009 & .004 & .766 & 1.329 & & & & \\
\hline $\begin{array}{l}\text { 7. Useful Skills } \\
\text { Ref. }\end{array}$ & $\begin{array}{l}\operatorname{DNA}(0) \\
\text { Agree(1) }\end{array}$ & .088 & .125 & .670 & 1.781 & & & & \\
\hline $\begin{array}{l}\text { 8. Self-confidence*** } \\
\text { Ref. }\end{array}$ & $\begin{array}{l}\text { DNA(0) } \\
\text { Agree(1) }\end{array}$ & -.637 & 17.070 & .391 & .715 & -.697 & 23.878 & .498 & .377 \\
\hline $\begin{array}{l}\text { 9. Independent Decisions** } \\
\text { Ref. }\end{array}$ & $\begin{array}{l}\text { DNA(0) } \\
\text { Agree(1) }\end{array}$ & -.953 & 28.371 & .272 & .548 & -1.006 & 33.447 & .366 & .260 \\
\hline $\begin{array}{l}\text { 10. Marks } \\
\text { Ref. }\end{array}$ & $\begin{array}{l}\operatorname{DNA}(0) \\
\text { Agree(1) }\end{array}$ & .076 & .217 & .783 & 1.488 & & & & \\
\hline $\begin{array}{l}\text { 11. Skills for success } * * \\
\text { Ref. }\end{array}$ & $\begin{array}{l}\text { DNA(0) } \\
\text { Agree(1) }\end{array}$ & -.629 & 12.358 & .375 & .757 & -.546 & 10.834 & .579 & .418 \\
\hline $\begin{array}{l}\text { 12. Personal Responsibility*** } \\
\text { Ref. }\end{array}$ & $\begin{array}{l}\operatorname{DNA}(0) \\
\text { Agree(1) }\end{array}$ & -.736 & 15.545 & .332 & .690 & -.700 & 15.537 & .49 & .351 \\
\hline $\begin{array}{l}\text { 13. Help from other } \\
\text { Students** } \\
\text { Ref. }\end{array}$ & $\begin{array}{l}\operatorname{DNA}(0) \\
\text { Agree(1) }\end{array}$ & -.575 & 20.240 & .438 & .723 & -.656 & 27.961 & .519 & .407 \\
\hline \multicolumn{10}{|c|}{ Expectations from Professors } \\
\hline $\begin{array}{l}\text { 14. Encourage } \\
\text { Ref. }\end{array}$ & $\begin{array}{l}\operatorname{DNA}(0) \\
\text { Agree(1) }\end{array}$ & -.114 & .711 & .684 & 1.164 & & & & \\
\hline $\begin{array}{l}\text { 15. Individual } \\
\text { Ref. }\end{array}$ & $\begin{array}{l}\operatorname{DNA}(0) \\
\text { Agree }(1) \\
\end{array}$ & -.160 & 1.527 & .661 & 1.098 & & & & \\
\hline $\begin{array}{l}\text { 16. Instructions } \\
\text { Ref. }\end{array}$ & $\begin{array}{l}\operatorname{DNA}(0) \\
\text { Agree(1) }\end{array}$ & -.187 & 2.060 & .642 & 1.071 & & & & \\
\hline $\begin{array}{l}\text { 17. Importance of Acad. } \\
\text { Honesty** } \\
\text { Ref. }\end{array}$ & $\begin{array}{l}\operatorname{DNA}(0) \\
\text { Agree(1) }\end{array}$ & -.616 & 15.127 & .396 & .737 & -.586 & 17.936 & .556 & .424 \\
\hline $\begin{array}{l}\text { 18. Personal Problems } \\
\text { Ref. }\end{array}$ & $\begin{array}{l}\operatorname{DNA}(0) \\
\text { Agree(1) }\end{array}$ & -.267 & 3.561 & .580 & 1.010 & & & & \\
\hline $\begin{array}{l}\text { 19. Help with Assignments } \\
\text { Ref. }\end{array}$ & $\begin{array}{l}\operatorname{DNA}(0) \\
\text { Agree(1) }\end{array}$ & .078 & .304 & .819 & 1.428 & & & & \\
\hline $\begin{array}{l}\text { 20. Reg. on Acad. Dishonesty } \\
\text { Ref. }\end{array}$ & $\begin{array}{l}\operatorname{DNA}(0) \\
\text { Agree(1) }\end{array}$ & .202 & 1.085 & .837 & 1.790 & & & & \\
\hline
\end{tabular}

$\dagger \mathrm{DNA}=$ do not agree $\quad * * \leq .05$ 